\title{
Barley: Global challenges and perspectives under non-tropical dry areas
}

\author{
RPS Verma \\ Barley Breeder, Biodiversity and Crop Improvement Program, International Center for Agricultural Research in the Dry \\ Areas (ICARDA), Morocco
}

\section{Article history}

Received: 04 Dec., 2018

Revised : 24 Dec., 2018

Accepted: 28 Dec., 2018

\section{Citation}

Verma RPS. 2018. Barley: Global challenges and perspectives under non-tropical dry areas. Wheat and Barley Research 10(3):123-137. doi. org/10.25174/2249-4065/2018/85893

\section{*Corresponding author}

Email: rpsvdwr@hotmail.com

(C) Society for Advancement of Wheat and Barley Research

\begin{abstract}
The International Center for Agricultural Research in Dry Areas (ICARDA) is one of the 15 CGIAR centers and has a global mandate for barley improvement, specifically for more than $\mathbf{1 6}$ million ha of barley grown in non-tropical dry areas across the globe. ICARDA's barley improvement program has been reorganized into spring barley for high and low input environments and winter barley programs to address the requirements of different agro-climatic conditions/regions. The spring barley program targets germplasm improvement for feed, food and malt purposes, targeting germplasm enhancement for global stressed environments in hulled and huskless barley. The winter barley program is basically focused to improve germplasm for colder regions in West and Central Asia where cold and frost are the major stresses along with drought. Each year, nearly 10000 advanced lines are evaluated for various agronomic, biotic and abiotic stress tolerances, and grain quality parameters in the breeding program. ICARDA's gene bank holds more than 33,000 barley accessions of which 2042 accessions are wild relatives of barley. The Focused Identification of Germplasm Strategy (FIGS) approach is utilized to mine efficiently this collection by selecting manageable subsets with higher frequencies for finding the sought traits. ICARDA's barley improvement program annually shares more than 330 sets of international trials and nurseries, with more than 60 collaborators in 35 to 40 countries. During 1977-2018, more than 269 barley varieties have been released across the globe by different countries, with direct introduction of germplasm from ICARDA's barley breeding programs, out of which 53 are released during last 10 years. In recent year, ICARDA's feed and food barley improvement program aims at improving nutritional qualities of barley, specifically Zn, Fe, and -Glucan contents. Simultaneously, the malt barley improvement is targeting to identify better malting quality germplasm for developing countries in Africa and Asia with a possibility of additional income to farmers through premium price for better quality in east Africa and south Asia.
\end{abstract}

Keywords: Barley, FIGS, Germplasm, Hordeum, ICARDA

\section{Introduction}

Barley (Hordeum vulgare L.) is grown over diverse eco-geographical environmental conditions as compared to other crop species, because of its hardiness to environmental variations. Barley is often considered as the only possible rainfed cereal crop under low input and stressful environments like, drought, heat and cold. This adaptability to the extreme and marginal conditions has led to widespread cultivation of this cereal throughout the world (Bothmer et al., 1995). The range of barley cultivation is from the tropics to high latitudes $(>600 \mathrm{~N})$ in Iceland and Scandinavia as well as in high latitudes up to 4500 meters above sea level (masl) in the Himalayas 
(Bothmer et al., 2003, Ceccarelli et al., 2008). Historically, owing to its rich dietary fiber and readily available energy, barley was utilized by the Roman gladiators, who were also called as "hordearii" (Andrew, 2008). Although globally the major utilization of barley is for feed and malting purposes, because of its nutritional value barley is consumed as a staple food in North and Sub-Saharan Africa (SSA), Central Asia, and South-West Asia. In terms of total production, barley ranks fourth in the world among

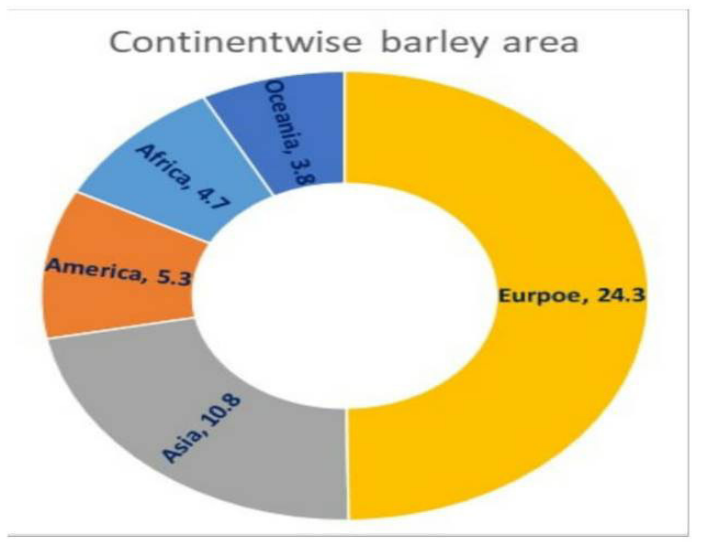

cereals after wheat, maize, and rice (FAOSTAT, 2016). It is grown by nearly 100 countries on about 50 million hectares (ha). Europe is the largest in terms of the barley area $(49.8 \%)$ and production $(61.1 \%)$ followed by Asia and Africa (Fig 1). In terms of productivity also Europe is highest with $3.4 \mathrm{t} /$ ha amongst all continents to closely followed by America (3.3 t/ha) (Fig.2). (Source http:// www.indexmundi.com/agriculture/?country=sa\&comm odity=barley\&graph=imports)

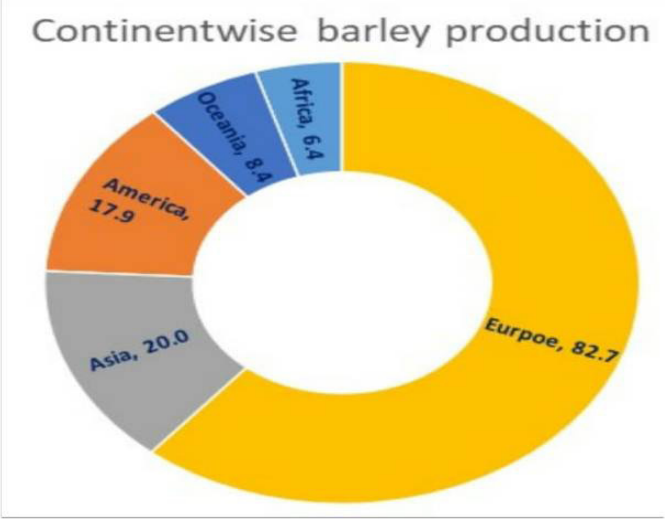

Fig. 1: Barley area (m ha) and production (m tons) in different continents of the world (FAOSTAT 2016)

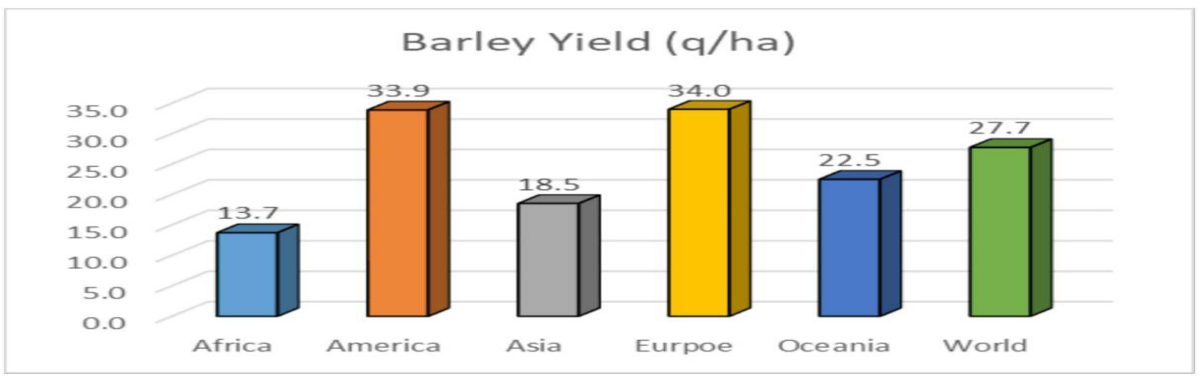

Fig. 2: Average barley yields in different continents (FAOSTAT 2016)

In the recent years, the area has stabilized after a decrease around the world, though the productivity (tons/ha) has continued to improve over the period (Fig 3). Most of the area where barley production ceased was replaced by wheat cultivation. Globally, the area under barley cultivation decreased from 80 million ha in the 1970's to less than 50 million ha in 2012 (FAOSTAT 2016). Reasons

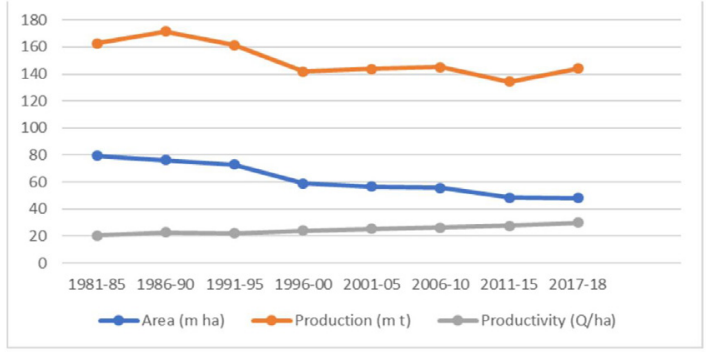

Fig. 3: Recent trends in global barley area, production and yields (FAOSTAT 2017) for the recent stabilization in barley area include the growing demand for malting barley both domestically and for international trade, and the warming climate requiring more water-efficient crops. Outputs have increased in most of the world's major barley producing countries, most notably in North Africa and the CIS countries in Europe.

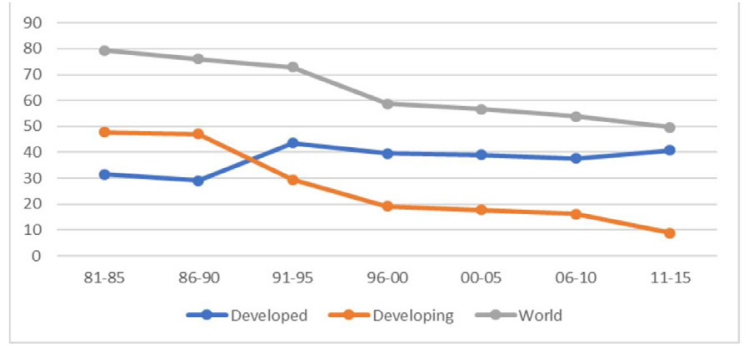

Fig. 4: Recent trends in barley area, developing, and developed countries (FAOSTAT 2017) 
The trends across the developing and developed countries are quite constrasting (Fig. 4), indicating that barley cultivation has been reduced in developing countries, where main uses are feed, food and forages, while it has increased in developed countries mainly because of its growing malting and feed demands. If the situation is analysed in different contonents, Asia has observed huge decline in barley cultivation during last two decades of the 20th century (Fig. 5), which has almost stabilised in the 21st century period, while Eurpoe has observed just opposite trends during these periods. In other continents America has observed gradual decline in area, while in Africa and Australia the area remained more or less similar.

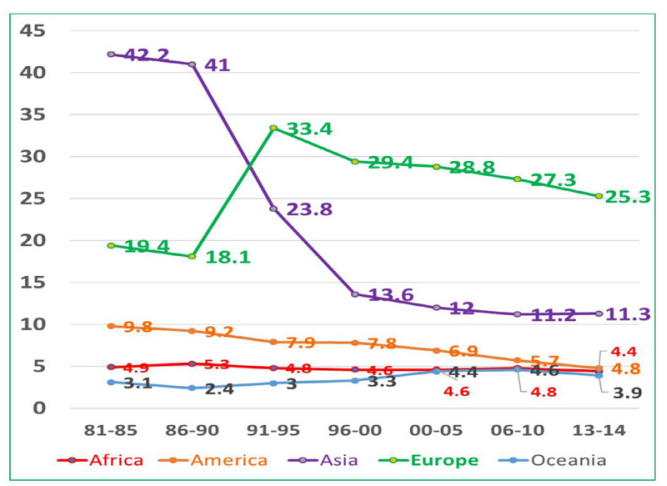

Fig. 5: Continent wise trends in barley area (FAOSTAT 2016)

The largest barley producing countries in the world are Russian Federation, Germany, France, Canada, Spain, Turkey, Ukraine, Australia and UK in this order, while in terms of area cultivated Russian Federation, Ukraine, Australia, Spain, Turkey, Canada, Morocco, Kazakhstan, France, Iran and Germany (in this order) are major countries (Table 1). In terms of yield, European countries Ireland, Germany, France, UK, Denmark, Austria and Sweden are having more than $5.0 \mathrm{t} / \mathrm{ha}$, while Argentina, Canada, USA, China and Brazil are countries outside Europe with more than $3.5 \mathrm{t} / \mathrm{ha}$ yield levels, which is well above the world average of $2.77 \mathrm{t} / \mathrm{ha}$. The major barley importing countries during 2016 include Saudi Arabia followed by China, Iran, Japan, Algeria, Jordan, Libya, Morocco and Tunisia in this order; however the annual imports may fluctuate in the north African countries based on adverse effect of drought on barley production as mainly it is rainfed crop in the region. Barley has considerable economic importance both in agriculture and industry in many countries. Globally, around 55-60\% of barley production is used for feed, 30-40\% for malt, 2-3\% for food and 5\% for seed (Ullrich, 2010). Use as a calorie food source for human consumption is mainly confined to marginal areas with problematic soils and scanty rainfall (Grando and Macpherson, 2005).
Table 1: Top twenty countries for barley area, production and yield, respectively globally

\begin{tabular}{|c|c|c|c|c|c|}
\hline Country & $\begin{array}{c}\text { Area } \\
(000 \\
\text { ha) }\end{array}$ & Country & $\begin{array}{l}\text { Production } \\
\quad(000 \mathrm{t})\end{array}$ & Country* & $\begin{array}{l}\text { Yield } \\
\text { (t/ha) }\end{array}$ \\
\hline $\begin{array}{l}\text { Russian } \\
\text { Federation }\end{array}$ & 8011 & $\begin{array}{l}\text { Russian } \\
\text { Federation }\end{array}$ & 15389 & Ireland & 7.58 \\
\hline Ukraine & 3233 & Germany & 10344 & Germany & 6.59 \\
\hline Australia & 3203 & France & 10316 & France & 6.3 \\
\hline Spain & 2769 & Canada & 10237 & UK & 5.85 \\
\hline Turkey & 2721 & Spain & 10058 & Denmark & 5.73 \\
\hline Canada & 2652 & Turkey & 7900 & Austria & 5.15 \\
\hline Moro & 1967 & Ukraine & 7562 & Sweden & 5.01 \\
\hline Kazakhstan & 1837 & Australia & 7472 & $\begin{array}{l}\text { Czech } \\
\text { Republic }\end{array}$ & 4.57 \\
\hline France & 1637 & UK & 7092 & Hungary & 4.07 \\
\hline Iran & 1600 & Argentina & 4705 & Argentina & 3.91 \\
\hline Germany & 1570 & USA & 4683 & Bulgaria & 3.9 \\
\hline Syria & 1500 & Denmark & 3950 & Canada & 3.86 \\
\hline USA & 1214 & Iran & 3200 & USA & 3.86 \\
\hline UK & 1213 & Poland & 2920 & Finland & 3.85 \\
\hline Argentina & 1203 & Morocco & 2723 & China & 3.83 \\
\hline Algeria & 1100 & Kazakhstan & 2539 & Croatia & 3.74 \\
\hline Ethiopia & 1048 & China & 2300 & Brazil & 3.72 \\
\hline Iraq & 900 & Sweden & 1940 & Slovakia & 3.68 \\
\hline Poland & 817 & Ethiopia & 1933 & Spain & 3.63 \\
\hline India & 790 & Finland & 1904 & Italy & 3.62 \\
\hline
\end{tabular}

* Only countries with $>50000$ ha area are considered for yield ranking. (Source FAOSTAT 2016)

Barley is the major dietary source for ruminant and nonruminant livestock, poultry and fish. Generally, the feed barley varieties yield more (10-20\%) than the malt barley varieties (Blake et al., 2010). This is because the malting industry prefers barley kernels of similar size, which allows for a more uniform malting process. Uniform kernels are easier achieved in a two-row variety, where seeds are more equally spaced than in six-row varieties, where due to crowding seeds in certain positions are larger than seeds in other positions. This additional requirement for uniform seed size in two-row barley has led to a relatively slower rate of yield increase achieved during breeding, as compared to six-rowed types. However, with the recent advancement in two-row spring barley breeding the difference in yield potential and yields achieved are being bridged. Worldwide, a significant increase of about $48 \%$ has been observed in the malt export and import values from 2008 to 2016 (Fig 6). However, prime focus of most of the breeding programs is still on the biotic and abiotic factors, which account for the majority of the losses in barley production and needs to be addressed strategically to achieve stability. Recent research regarding dietary composition in food barley has renewed interest in this end-use, confirming the health benefits of barley in human diets (Brockman et al., 2013; Sullivan et al., 2013) through more soluble dietary fiber, beta glucan content and higher amylases activity then other food cereals. Barley is a common diet for diabetic people and 
its easy digestion and fast release of energy makes it a good food. In comparison to other cereal crops, barley has a better fodder value including grain and straw. In most of the developed countries, barley straw is used for animal bedding, whereas it is used as animal feed in the developing countries, in addition to the grazing use in most of the West Asia and North Africa.

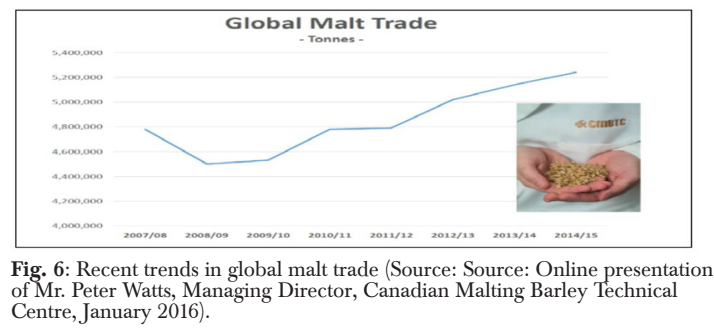

Under variable climatic conditions within the growing season, such as drought, heat or cold, barley gives comparably higher yields than other small grain cereals. Being one of the most widely adapted crops, the barley germplasm pool has the potential to contain enough genetic diversity to breed for adaptation to different environmental conditions. Moreover, the ample barley germplasm resources available worldwide (Bockelman and Valkoun, 2010), including wild relatives, likely contain beneficial allelic variation that new molecular breeding technologies can exploit (Newton et al., 2011). Owing to its vast morphological and environmental adaptability, various types of barley (winter, spring, two-row, six-row, awned, awnless, hooded, covered, naked, malting, feed and food types) are grown throughout the world.

\section{Barley cultivation and genetic improvement}

The original area of barley cultivation is assumed to have been the Fertile Crescent, stretching from present-day Israel and Jordan to Syria and Southern Anatolia and to the Zagros Mountain area in Western Iran (Bothmer and Jacobsen, 1985). However, with evidence found in Morocco (Molina-Cano and Conde, 1980; Salcedo et al., 1984; Moralejo et al., 1994; Molina-Cano et al., 1987, 1999, 2002, 2005) and in South-eastern Himalaya and Tibet (Xu, 1982), the general agreement on the monocentric origin of barley was challenged. Still the Near East, Tibet, Abyssinia, and the Western Mediterranean region were proposed as centers of diversity for barley. The Abyssinian region in the eastern part of Africa, including the modern countries as Ethiopia, Eritrea, Djibouti, and Somalia, is believed to represent an important center of diversity for barley. Barley is believed to have been cultivated in this region as early as 3,000 BC (Gamst, 1969). The region possesses diversity of climates, soils, topography, social environments, vegetation cover, and livestock. The first "Ethiopians" to have cultivated barley are believed to be the Agew people, in about 3,000 BC (Zemede, 1996). Evidence from a flavonoid study also raised doubt on a mono-phyletic origin of barley, arguing that through long-term introgression of the relatively fewer wild relative genes remained swallowed in the gene pool of cultivated barley in Ethiopia (Endeshaw, 1983). Furthermore, very recent work considered Ethiopia an independent center of barley diversification and a potential domestication site (Orabi et al., 2007). Indeed, Ethiopian barleys have been isolated so long that two of them, irregular barley and deficient barley, were for a time considered distinct species. The long history of barley cultivation and the diversity in soils, climate, altitude and topography together with geographical isolation for long periods have resulted in a large number of landraces and traditional agricultural practices (Berhanu et al., 2005). There is high diversity observed among Ethiopian barleys with six-rowed, two-rowed, deficient and irregular types, hulled and hull-less, and with different grain colors. The variation in Ethiopian barleys has been attributed to mixing of types in the fields and associated with mutation, frequent natural hybridization and disruptive selection (Zemede, 1989). The variation might have resulted from the highly heterogeneous environment, on which farmers' preferences and selection for desirable traits are imposed. Recent population genomics studies towards understanding intriguing patterns in the cultivated barley genomes that shed light on the trajectory of barley domestication, have postulated that there are three possibilities for the domestication/ origin of cultivated barley. The first is that the hypothetical wild progenitor population could have had a highly admixed ancestry that was passed down to the cultivated lineage. The admixed wild barley genotypes frequently occur at the contact zones between the modern wild populations. The second hypothesis is that the wild progenitor lineage was not admixed and the recurrent gene flow from wild into the proto-domesticated populations happened during the transition to cultivation gradually creating the heterogeneous admixture patterns. The third and perhaps the likeliest scenario is a combination of the ancestral population structure and the gene flow (Pankin and von Korff, 2017).

\section{Biotic stresses in barley}

Several diseases and insects are constraining barley production and productivity in different parts of the world (Table 2.2) with varying intensities. The most important fungal diseases in barley include net blotch (net form and spot form), scald, stripe, leaf and stem rusts, spot blotch, 
powdery mildew, Fusarium head blight, and covered smut, respectively, while barley yellow dwarf virus (BYDV) is the major viral disease. Incidence and severity of these diseases varies from country to country and season to season.

Table 2: Important disease and insect pests affecting barley production

\begin{tabular}{ll}
\hline Pests & Pests \\
\hline Diseases & Net form of net blotch (Pyrenophora teres), spot form of \\
& net blotch (P. teres f. sp. maculate), scald (Rhynchospo- \\
& rium commune), stripe rust (Puccinia strifformis hordei), \\
& powdery mildew (Erysiphe graminis), head blight \\
& (Fusarium heterosporium), covered smut (Ustilago \\
& $\begin{array}{l}\text { hordei), stem rust (Puccinia graminis f. sp. hordei }), \text { spot } \\
\text { blotch (Bipolaris sorokiniana) }\end{array}$ \\
Virus & Barley yellow dwarf virus (BYDV) \\
Insects & $\begin{array}{l}\text { Barley shoot fly (Delia arambourgi Seguy, D. flavi- } \\
\text { basis Stein.), Russian wheat aphid (Diuraphis noxia } \\
\text { Mordvilko), and chafer grub (Melolontha spp.) }\end{array}$ \\
\hline
\end{tabular}

Scald (Rhynchosporium commune) has become one of the most prevalent diseases in North and East Africa. The infection is favored in cool and moist areas, and yield losses of up to $40 \%$ have been observed (Shipton et al., 1974; Zhan et al., 2008). Net blotch is most important disease in every barley-growing region of the Africa and West Asia. It exists in two forms; P. teres f. sp. teres causing net-form net blotch (NFNB), and P. teres f. sp. maculata causing the spot-form net blotch (SFNB). As a complex it poses a serious threat to yield stability of barley (Tekauz, 1990), causing considerable damage both quantitatively and qualitatively. For example, in Morocco a yield reduction of $29 \%$ has been reported (ElYousfi and Ezzahiri, 2002). Even a complete crop failure can occur under severe epidemics (Mathre, 1997). Malt quality traits, such as kernel plumpness and malt extract, can also be adversely affected due to net blotch disease (McLean et al., 2009). Stripe rust (Puccinia striiformis $\mathrm{f}$. sp. hordei) is very common in South Asia, Africa, West Asia, USA, especially in the cooler regions. This disease has the potential to cause a complete crop failure. Under experimental conditions yield losses of 20-72\% have been observed (Stubbs, 1985; Marshall and Sutton, 1995). Studies conducted in Ethiopia indicated that yield losses due to important fungal diseases range from $6.9 \%$ to $40.2 \%$ for stripe rust; $14.25 \%$ to $24.55 \%$ for net blotch and up to $70 \%$ for scald. (Mulatu and Stefania, 2011). The leaf rust (Puccinia hordei) is global in distribution across the continents where climate is a little warmer. Barley stem rust (Puccinia graminis $\mathrm{f}$. sp. hordei) is another important rust disease in some regions of SSA (Steffenson, 1992). Severe infection affects yield by reducing the size and weight of the kernels. A new virulent stem rust race
TTKSK (synonym of Ug99) has been reported from Uganda in 1999 and was shown to be virulent on $70 \%$ of the barley varieties worldwide. This race has spread to other countries in Africa and has the ability to cause crop failure. In susceptible cultivars, yield losses of more than 50\% have been observed (Dill-Mackay et., 1991; Harder and Legge, 2000). Powdery mildew caused by Blumeria graminis f. sp. hordei is a cool weather disease in all parts of the world, where conditions are drier during early vegetative crop growth. It can cause yield losses of up to $14 \%$, which may increase with early onset of infection due to high inoculum pressure (Mathre, 1997; Braun et al., 2002). Fusarium head blight (FHB) is also an important disease in cool and humid regions of the world especially USA, Canada, China and other regions with good rainfall at reproductive stages. There are three species inflicting high disease severity, Fusarium graminearum teleomorph, Fusarium culmorum, and Fusarium crookwellense (Salas et al., 1999; Xue et al., 2006). It can adversely affect the malting quality and flavor of the beer produced from infected kernels. Many Fusarium species causing FHB produce mycotoxins (such as deoxynivalenol (DON) and nivalenol, which render the infected grain unfit for human and animal consumption (Steffenson, 2003; Joffe, 1986). Spot blotch, caused by Bipolaris sorokiniana, occurs under warm and humid weather, such as in the sub tropic regions of SSA and South Asia. The yield loss of up to $30 \%$ is quite common in barley-growing regions and can be higher in more disease favorable environments (Tinline, 1988; Fetch and Steffenson, 1994). Barley yellow dwarf, caused by Barley Yellow Dwarf Virus, is the most important viral disease of barley worldwide, as well as in north Africa and SSA. An early infection can result in $100 \%$ yield loss (Mathre, 1997), and up to 80\% yield loss has been reported in Ethiopia (Mulatu and Stefania, 2011). Barley shoot fly (Delia arambourgi Seguy, D. flavibasis Stein.) and Russian wheat aphid (Diuraphis noxia Mordvilko) are the most important insects of barley, inflicting huge losses. Studies indicated that they can cause yield losses up to 79\% and 56\%, respectively (Miller and Adugna, 1988; Tafa and Tadesse, 2005). Weeds constitute another major biotic constraint in barley production in North and East Africa, South Asia, Europe and other regions. In Ethiopia, grassy weeds have been documented to incur yields losses as high as 60\% (Takele et al., 2006). The crop suffers the greatest yield reduction due to weed competition up to its third to sixth leaf stages (Stroud, 1989).

\section{Abiotic stresses}

Barley is a winter season crop with better adaptation to dry regions including higher altitude regions and it is grown in a wide range of agro-climatic regions under several 
production systems. At altitudes of about 3000 masl or above, it may be the only crop grown that provides food, beverages and other necessities to many millions of people, globally. Barley grows best on well-drained soils and can tolerate higher levels of soil salinity than most other crops. Food barley is commonly cultivated in stressed areas where soil erosion, occasional drought or frost limits the ability to grow other crops in Ethiopia (Berhanu et al. 2005). The most important abiotic stresses in barley production in dry areas are drought, heat, cold and frost, low soil fertility, soil salinity and soil acidity (low soil $\mathrm{pH}$ ). In the mid- lowland and rift valley areas in different SSA countries, moisture stress is significantly limiting barley production and productivity. Late onset and early cessation of rainfall are predominant phenomena in most of the countries. Rainfall distribution is often erratic, resulting in a shortage of precipitation during critical growth stages of the crop. Also, barley does not thrive in poorly-drained soils and water logging can be a serious abiotic stress limiting the growth and tillering severely. Among cereal species, barley is regarded as the most sensitive crop to soil acidity (Wang et al., 2006). Currently, it is estimated that about $40 \%$ of the total arable land of Ethiopia is affected by soil acidity (Abdenna $e t$. al., 2007; Taye, 2007; Desta, 1987), with similar situation existing in Eritrea, Kenya and Tanzania also with respect to drought and acid soils. In general, the national breeding programs in countries like Eritrea and Ethiopia, have given more emphasis to the evaluation of landraces for drought and cold/frost stresses under low to medium inputs rather than replacing the local germplasm by exotic materials in the beginning of the program till mid-eighties (Berhanu et al.,2005). Thereafter, to enrich and improve the germplasm base, exotic germplasm of both six-row feed/ food and two-row malt types have been introduced from ICARDA and other sources in SSA, especially in Ethiopia and Eritrea (Grando and Gomez Macpherson, 2005). A critical shortage of improved barley varieties adapted to low-moisture stress conditions is a major problem and hence farmers are forced to grow low yielding genotypes in Eritrea, Ethiopia and Kenya. Therefore, the breeding programs in Africa and West Asia, have relied mostly on germplasm introduced from exotic sources, particularly from the International Centre for Agricultural Research in the Dry Areas (ICARDA). To date, several thousands of genotypes received from ICARDA as International Nurseries have been evaluated in low moisture conditions and several genotypes and lines with the desired drought and cold tolerance have been identified.

\section{Barley Improvement Program at ICARDA}

The International Center for Agricultural Research in Dry Areas (ICARDA) is one of the 15 CGIAR centers and has a global mandate for barley improvement, specifically for non-tropical dry areas across the globe. Realizing the importance of barley as the fourth major grain crop after rice, wheat, and maize, ICARDA has been engaged in contributing research and development of barley at global scale since its establishment. Barley is grown in more than 48 countries with $>16 \mathrm{~m}$ ha in dry areas under ICARDA immediate mandate regions (Figure 7). There are more than 228 million farming families who are directly engaged in barley production in developing countries with potentially 55 million further beneficiaries arising from off-farm activities in barley value-chain (FAOSTAT 2016).

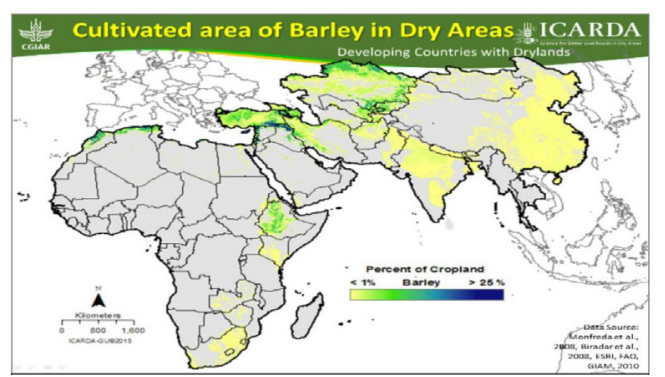

Fig. 7. Distribution of barley growing developing countries in Asia and Africa (Source: CRP Dryland Cereals).

Barley is the keystone crop in non-tropical dry area across the globe. Livelihood of poor farmers and their livelihood strategy which is based on livestock (especially small ruminants) they own, are dependent on barley (both as food and feed and forage crops). In dry areas, a conservative estimate indicates that one ha of barley production can normally supports 5 small ruminants (sheep and goat) for feed and fodder for one year. Therefore, potentially barley has been key feed and forage crops supporting more than 80 million small ruminants in dry area. It is evident that small ruminants are the livelihood assets for small farmers especially in dry areas and barley has a pivotal role in livelihood of poor farmers. The other potentials as dryland crop includes harnessing benefits from value addition of natural properties of barley grain such as food crop (value added food products), forage (hydroponic green forage throughout the year with limited water use), in addition to the increasing use for malting (alcoholic and non-alcoholic beverages), and nutraceutical food (barley powder and barley flakes rich in -glucan to lower cholesterol, higher antioxidant activities) in developing world. ICARDA's barley improvement program is streamlined with CGIAR Research Program on Dryland Cereals (CRPDC) during its phase-I and now with the CRP on Livestock. The barley research is organized with six focal countries (Table 3) in the five regions to address the needs of many target countries. However, barley being the global mandate crop, ICARDA has been serving non-focal countries as well through direct germplasm 
sharing upon indents/requests. Specific constraints of barley improvement in focal regions are being addressed with greater collaboration with the countries which have competence and capabilities in the region and ICARDA is taking up research for development (R4D) for the target countries with the help of these focal countries.

Table 3. Focal and target countries with production constraints under CRP DC on barley.

\begin{tabular}{|c|c|c|c|}
\hline Region & Focal Country & Targeted countries & Production constraints of the region \\
\hline North Africa & Morocco & Algeria, Tunisia, Libya, Egypt, Mauretania & $\begin{array}{l}\text { Drought and heat and stress, diseases and } \\
\text { insect pests }\end{array}$ \\
\hline East Africa & Ethiopia & $\begin{array}{l}\text { Eritrea, Kenya, Tanzania, South Africa, } \\
\text { Yemen }\end{array}$ & $\begin{array}{l}\text { Lower productivity of malt and food barley, } \\
\text { drought, acidic soils diseases and weeds }\end{array}$ \\
\hline South Asia & India & $\begin{array}{l}\text { China, Pakistan, Afghanistan, Nepal, Bangla- } \\
\text { desh, Bhutan }\end{array}$ & $\begin{array}{l}\text { Productivity of malt barley (demand increas- } \\
\text { ingly } 10-15 \% \text { annually), lack of high yield- } \\
\text { ing varieties for marginal areas, food (high } \\
\text {-Glucan), biotic stresses (stripe \& leaf rusts, } \\
\text { foliar blights, aphid) }\end{array}$ \\
\hline West Asia & Iran & Syria, Iraq, Jordan, Lebanon, Armenia, & $\begin{array}{l}\text { Cold, heat and drought stress, biotic stresses } \\
\text { (leaf rust, powdery mildew and scald) }\end{array}$ \\
\hline West Asia, & Turkey & $\begin{array}{l}\text { Syria, Iraq, Jordan, Lebanon, Armenia, } \\
\text { Georgia, Azerbaijan, }\end{array}$ & $\begin{array}{l}\text { Cold and drought stress, biotic stresses (net } \\
\text { blotch, scald, insect pests) }\end{array}$ \\
\hline Central Asia & Kazakhstan & $\begin{array}{l}\text { Uzbekistan, Azerbaijan Tajikistan, Kyrgyz- } \\
\text { stan, Turkmenistan }\end{array}$ & $\begin{array}{l}\text { Drought, heat, cold and salinity stresses, } \\
\text { lower productivity of malt and feed varieties, } \\
\text { diseases and insect pests }\end{array}$ \\
\hline
\end{tabular}

Rest of the world dry areas (Australia, Latin America, Europe) barley requirements are also addressed through elite germplasm distribution

Barley is the climate resilient crop for present and future. Barley is successfully grown and cultivated in drylands of arid, semi-arid and temperate regions of the world in general and Africa and Asia in particular. Barley is the most important feed and food crop for climate change considering its resilience and buffering capacity as well as to adapt quickly to the gradients of moisture stresses and short growing season. Having early vigor and being faster vegetatively growing crop among small grains, it is adapted to the raising temperature and frequent droughts. The range of cultivation of barley is from the sea level to as high as 10-12 thousand feet high in the cold deserts (where no other crop can be grown), providing the human food, and feed and forage for livestock. The added advantage of thriving in cold stress with faster biomass production makes winter type barley a possible option in cold regions of west and central Asia. The worldwide increasing salinity problem also makes barley as a crop for marginal and problematic soils. In the dryland area, major cropping system is cereal-food legume (and/or feed) based and barley dominates as major cereal in the cropping systems prevailing in the arid and semi-arid zones. In the CRP programs, CRP Dryland Cereals (DC) in addition to feed and fodder uses, barley as food crop was also given high priority, especially for the North Africa and East Africa, where value addition for making different barley products for small scale industries is being taken up by national programs. Morocco considers barley as a major food crop and has recently released two huskless barley cultivars from ICARDA germplasm introduction with higher Fe,
Zn and $\beta$-glucan. Currently barley has been included in the CRP on Livestock, with objectives of feed, forage and dual purposes crop for the dry areas to support the livestock in the target regions in Africa and Asia. The short and fastgrowing season of barley perfectly fits farmer cropping systems with various legumes. Under the one year two seasons rotations also barley in winter season is an ideal crop for rotation with legumes /cereals of summer season. In ICARDA, the major components of spring barley research are low input program for stressed environment (Feed, Food and forage barley), and high input program for optimal environments (Food, feed and malt barley). The winter barley program addresses the food and feed aspects under cold and drought stressed environments mainly from Turkey base. In addition, pre-breeding using wild barley and landraces and trait discovery in barley genetic resources are other important aspects. Every year nearly 10000 elite lines are evaluated to meet the demand of diverse genetic materials targeted to specific ecological regions and niche specific preferences of farmers. Annually ICARDA contributes a total of more than 350 sets of trials and nurseries to more than 60 collaborators across 35-40 countries (majority developing countries) through International Nursery program. The success of continuous improvement of ICARDA germplasm lies in the fact that ICARDA barley program has used barley landraces and wild germplasm for trait discovery and trait integration for several years. ICARDA's gene bank holds more than 33000 barley accessions of which 2042 accessions are wild relatives of barley. Recently our gene bank has 
successfully used Focused Identification of Germplasm Strategy (FIGS) to mine potentially important germplasm for various traits. Currently ICARDA is collaborating with several institutes and organization globally mining barley genetic resources using FIGS approaches including BARLEY-CAIGE program with Australian partners. So far, seven FIGS sub-sets have been developed in barley specifically targeted for abiotic (drought) and biotic stresses (Powdery mildew, net blotch, yellow rust, BYDV and barley gall midge). FIGS approach uses algorithms linking environmental conditions with sought traits to select subsets with fewer accessions having higher probability of finding the sought traits. This approach has already allowed to identify adequate sources of resistance to PM, BYDV, Net blotch and drought. The genetic diversity of ICARDA's barley programs is high and comparable to several international collections. In the past several 2-rowed by 6-rowed crosses have been made, therefore, an overlap between two-rowed and six-rowed germplasm is reported often within ICARDA's barley genetic resources. During 1977-2018, more than 269 barley varieties have been released across globe by different countries, with direct introduction of germplasm from ICARDA's barley breeding programs, out of which 18\% releases were in developed countries including Australia and Canada. During last 10 years period 53 cultivars have been released in 15 countries (Table 4), where Iran, Ethiopia, China and India are major beneficiaries. These releases do not include varieties developed through hybridization with ICARDA germplasm.

Table 4: New cultivars released in different countries as introductions from ICARDA elite germplasm during last 10 years

\begin{tabular}{|c|c|c|}
\hline Country & Variety & Total \\
\hline Afghanistan & Balkh 013, Shamal 013 (both 2013) & 2 \\
\hline Algeria & Fouara $(2012)$ & 1 \\
\hline Azerbaijan & Gudratli 48, Garabakh33 (both 2013), Deyanetli (2016), Sadig (2017) & 4 \\
\hline Brazil & Savavnna (2012) & 1 \\
\hline China & $\begin{array}{l}\text { Yunging-1 (2009), Yundamai4, Yundamai5, Yundamai6 (All 2013), Yundamai7, Yunda- } \\
\text { mai8 (both 2014) }\end{array}$ & 6 \\
\hline Cyprus & Lefka, Morfo and Trikomo (all 2010) & 3 \\
\hline Ethiopia & $\begin{array}{l}\text { Diribe (2010), Gobe, IBON 174/03(both 2012), HB 1963, HB 1964, Singitan (all 2016), } \\
\text { Moata and Adoshe (both 2018) }\end{array}$ & 8 \\
\hline India & $\begin{array}{l}\text { BHS380 (2009), UBP } 1008 \text { (2011), PL } 807 \text { (2012), BHS400 (2013), VLB118 (2014), } \\
\text { VLB130 (2018) }\end{array}$ & 6 \\
\hline Iran & $\begin{array}{l}\text { Nimruz and Mahor (2008), Yousef, Fajre } 30 \text { and Bahman (2009), Khorram (2012), Nader } \\
\text { (2013), Ansar (2014), Behdan, Mahtab, Norooz (all 2018) }\end{array}$ & 11 \\
\hline Mexico & Doña Josefa (2008) & 1 \\
\hline Morocco & $\begin{array}{l}\text { Chifaa (INRA1791), Assiya (INRA1793) (both 2016) Khnata (INRA1794) and Ksiba } \\
\text { (INRA 1796) (both 2018) }\end{array}$ & 4 \\
\hline Peru & La Milagrosa (2008) & 1 \\
\hline Tajikistan & Pulodi (2010) & 1 \\
\hline Tunisia & Kounouz (2012) & 1 \\
\hline \multirow[t]{2}{*}{ Turkey } & Kendal (2013) Burkut, Hevsel (both 2017) & 3 \\
\hline & Total & 53 \\
\hline
\end{tabular}

The barley program of ICARDA has been recently reorganized and streamlined with CRP DC. The spring barley (low and high inputs) programs have been relocated in Morocco, while winter program is based in Turkey. Lebanon is serving as hub of International Nursery program and new evaluation sites in Ethiopia and India platforms will further add to the efficiency of the program. Despite the recent reorganization of ICARDA program in different location, barley program has successfully delivered useful genetic resources to its collaborators across globe. Recently, malt and nutrient dense food barley (high Zn, Fe and $\beta$-Glucan) component have received greater attention at ICARDA to meet increasing demand of diverse raw materials required by barley industry in developing countries. The latest inclusion in ICARDA barley program is the malting quality improvement aspects, recently addressed through Private-Public Partnership (PPP), in Mexico with M/s Impulsora Agricola de SA (IASA) a joint subsidiary of AB InBev and Heineken groups. The program has identified advanced genotypes with excellent grain and malt traits in two and six row types, which have great potential in East Africa and South Asia regions where the demand on malting barley is on continuous rise in recent past. Ethiopia 
and India national program are making good use of such genotypes in evaluation and release in the country for meeting the requirement of malting and brewing industry. Another aspect of malt-based energy drinks for infants and children is also targeted with developing cultivars for non-brewer's malt.

\section{Bottlenecks and future prospects for barley improvement Genetic bottleneck}

Since and during domestication, certain selection pressures force the crop plants to change in their genetic base, which "resulted in its fixation and narrowing in cultivated barley in comparison to wild species (Tanksley and McCouch, 1997). Many genes were lost during the process of domestication and modern breeding, which now warrants introgression of new genes in barley (Kilian et al., 2006). The available genetic resources need to be investigated with modern genetic tools for the much-needed increase in yield potential, as in the past linkage drag, involving undesired linked genes, often hampered their use as parental stocks in plant breeding. Wild gene pools and landraces can be utilized for increasing crop productivity and stress resistance/ tolerance under changing environmental conditions (Bockelman and Valkoun, 2010; Kilian et al., 2006; Xu et al., 2012). Sub Saharan and North Africa are the home of barley landraces, which are genetically heterogeneous populations comprising near-homozygous inbred individuals and hybrid segregates generated by a low level of random outcrossing among those individuals in each generation (Nevo, 1992). These heterogeneous plant varieties are still being reproduced by farmers as populations, and which are still subject to both artificial and natural selection. The traits derived from landraces of barley are principal contributor towards agricultural production, representing over 10 million hectares worldwide comprising nine countries with Canada, USA and ICARDA in Syria being the major contributors (Altieri, 2004). In many developing countries, farmers maintain traditional varieties independently with seed often obtained from relatives, neighbors or local markets (McGuire, 2008). The genetic structure of these landraces may be considered as an evolutionary approach to survival and performance under arid and semi-arid conditions (Schulze, 1988), and can hopefully provide a source of alleles for adaptation to climate change.

Pre-breeding and exploration of genetic diversity A considerable yield advantage of certain landraces over modern varieties in very low rainfall conditions, with little or no use of inputs, has been reported by Ceccarelli and Grando (1996). Barley landraces have developed abundant patterns of variation and would represent a largely untapped reservoir of useful genes for adaptation to biotic and abiotic stresses (Brush, 1995) to contribute to the improvement of modern varieties (Hadjichristodoulou, 1995; Veteläinen, 1994). As an example, for biotic stresses, nineteen major genes $(R p h)$ for resistance against Puccinia hordei have been identified and mapped in barley landraces and wild barley $(H$. vulgare ssp spontaneum) (Weerasena et al., 2004). Generally, in both developing and developed countries, the use of wild crop relatives such as $H$. spontaneum and landraces is not common in barley breeding (Grando et al., 2001). Their breeding programs focus on using newly released varieties and elite germplasm as parents for hybridization. Although most of the recent breeding material is of course originally derived from previous landraces, still the breeding efforts rely on a relatively narrow gene pool of modern germplasm. Barley landraces are expected to be a source of valuable germplasm for sustainable agriculture in the context of future climate change and provide improved adaptation to local environments (Bellucci et al., 2013). These collections of landraces are looked upon as important sources of germplasm with which to enrich modern barley varieties (Tester and Langridge, 2010). Exploitation of these landraces in modern crop breeding requires understanding of their phenotypic characteristics, environmental adaptations and the underpinning genetics, along with their evolutionary relationships. Pre-breeding efforts are essential to be taken up by dedicated basic research programs, as the main breeding programs are focused in variety development, often dependent either on introductions or limited hybridization between improved varieties. The obvious reasons may be the shortage of funds and manpower and priority setting by the concerned institutes. That the incorporation of noble genes from wild relatives can really be achieved in modern cereal breeding has successfully been proven in bread wheat breeding by CIMMYT (van Ginkel and Ogbonnaya, 2007), resulting in several dozens of commercial varieties released to farmers by national programs containing a wild wheat relative as a parent. Their approach can serve as an example for barley breeding.

\section{Breeding goals and projected progresses}

Besides introducing genetic diversity from wild relatives and landraces, a second major focus to improve barley production is on enhancing human and infrastructure capacity of the barley researchers to successfully use modern biotechnological tools. In terms of traits, after 
yield and yield stability, priority is to be given to disease and pest management through host resistance for sustainable production. Uptake of modern varieties will also be enhanced if distinct varieties are bred addressing various agro-ecosystems, including the marginalized, dry, hot environments and the more optimum environments with irrigation potential. Hand-in-hand with genetic improvement, soil fertility and agronomic management of stressed soils, such as due to acidity, salinity and waterlogging, needs to be undertaken. This requires close cooperation between breeders, agronomists and also physiologists. Market competitive production will be enhanced if targeted focus is given to improving malting quality to a share of the new varieties. Nutritional security can be improved through micronutrient enrichment by bio-fortification of new varieties, although its priority will depend on other high-priority needs in new varieties. Mechanization emphasis is becoming essential and need for suitable cultivars to adopt the requirements such as non-brittle spikes, becomes an important breeding objective. In some parts of SSA increased and more erratic drought is predicted, while in others rainfall may increase but fall in the form of a limited number of strong outbursts. This requires that research scientists and others along the pathway to provide seed of adapted varieties to farmers need to be very vigilant and focused on monitoring change, so the R\&D focus and scope can be adjusted quickly.

\section{Application of biotechnologies}

With the advent of molecular markers, the ability to utilize wild relatives in crop improvement has greatly improved (Xiao et al., 1996). In many breeding programs molecular breeding complements conventional breeding, as these new tools allow breeders to identify and follow desired alleles through marker-assisted selection (MAS) in the breeding/selection process (Rao et al., 2007). The progress in biotechnology has opened up enormous possibilities of introgression of specific traits and, hence, broadening of genetic base through pre-breeding. Even the large size of the barley genome has not restricted the progress in molecular mapping. The techniques leading to this development initially included EST resources for gene-based markers, development of a commercial micro-array with 23000 barley genes, and the synthesis of DArT markers for specific chromosomal regions. Comprehensive consensus maps provided means to select markers for chromosomal regions and allow comparative mapping by exploring information available for other grasses. Then high-throughput genotyping (SNP, DArT) increased data generation speed. Increasingly genomic analysis of germplasm can be outsourced to commercial parties, and in-house emphasis is on interpreting the returned data through bio-informatics. Consortia efforts are in progress for the sequencing of barley genome (http://barleygenome.org), which will facilitate rapid cloning of genes and increase the number of markers available for mapping QTL and implementing markerassisted selection. The barley genome is one of the largest in cereal crops and a substantial body map of genetic and genomic resources have been produced (Martin et al. 2017) as high-quality reference genome assembly for barley. Transformation efficiencies in barley continue to increase and this is allowing the demand for an evaluation of gene function using transgenic tools. However, the pace of gene discovery is also increasing, with the availability of more sequenced crop genomes and improved genomics tools, meaning that even more genes will need to go through a transformation pipeline to allow the study of gene function (Wendy 2012). A range of tools are available to help achieve the level and specific pattern of transgene expression required, but there are still gaps in the range of promoters available for use in barley that needs to be addressed. However, further advances in this technology are required before it can be used routinely in barley. A key remaining challenge is the genotype dependence of most wheat and barley transformation systems and this continues to restrict the application of the technology. It is, however, likely that, by understanding and manipulating plant genes important in either the plant regeneration process or in susceptibility to Agrobacterium, it will be possible to address issues of genotype dependence and to improve transformation efficiencies further. Marker-based technologies together with doubled haploid technologies and "speed breeding" have almost halved the time of variety development in some barley breeding programs (Hickey et al., 2017). Genome wide association studies (GWAS) with information on linkage disequilibrium (LD) have revolutionized the QTL studies to unravel the genetic architecture of complex agronomic traits. New QTL for biotic stresses like net blotch (Amezrou et al. 2018, Gyawali et al. 2018b), spot blotch (Gyawali et al. 2018a) and stripe rust (Visioni et al. 2018) and grain micronutrients (Gyawali et al. 2017) have been discovered in global collections at ICARDA in association with other institutions. As an outcome, genomic selection using entire genome information is proving the latest tool in making breeding more precise and faster. Therefore, the strategy for future barley breeding should be built on in-depth knowledge of the barley genome and promote the use of both older and modern proven technologies to achieve the final goals 
more rapidly. Besides, numerous health claims attributed to barley in general (Ames and Rhymer, 2008), several studies have demonstrated the specific health-promoting properties of $\beta$-glucans (Wood and Beer, 1998; Newman and Newman, 1992). $\beta$-glucans have been implicated in lowering plasma cholesterol, improving lipid metabolism, reducing glycemic index and the risk of colon cancer (Behall et al., 2006; Brennan and Cleary, 2005, Keenan et al. 2007, Li et al. 2003). Pearling by-products have interesting amounts of bioactive compounds (dietary fiber and $\beta$-glucans) and could, therefore, be proposed as potential ingredients for manufacturing of functional food (Marconi et al., 2000). Development of new varieties with desired traits offer farmers greater flexibility in adapting to climate change, including traits that confer tolerance to drought, heat and salinity, and early maturation in order to shorten the growing season and reduce the crop's exposure to risk of extreme weather events (Lybbert and Summer, 2010). Barley farmers pursue a wide range of crop and livestock enterprises that vary not only within but across the major agro-ecological zones. Barley certainly contributes to their livelihoods as well as for their livestock in terms of grain, straw and grazing in the dry environments. The additional income from the cultivation of malt barley with private partnership is an important factor in promoting barley cultivation in the East Africa and South Asia. Understanding farmers' response to climatic variation is, therefore, crucial in designing appropriate copping strategies to climate change for poor countries, which are highly vulnerable to the effects of climate change.

\section{Acknowledgements}

The author is thankful to all individuals, who helped directly and indirectly in preparation and improvement of this manuscript. The help extended by all national partners to carry out ICARDA barley research program is sincerely acknowledged.

\section{References}

1. Abdenna, D., C. Negassa and G. Tilahun. 2007. Inventory of Soil Acidity Status in Crop Lands of Central and Western Ethiopia, Utilization of Diversity. (Abst.) In: Land Use Systems: Sustainable and Organic Approaches to Meet Human Needs, 9-11 October, 2007, Tropentag, Witzenhausen, Germany.

2. Altieri, M.A. 2004. Linking ecologists and traditional farmers in the search for sustainable agriculture. Frontier in Ecology and the Environment 2: 35-42.

3. Ames, N.P. and C.R. Rhymer. 2008. Issues surrounding health claims for barley. Journal of Nutrients 138: 1237-1243.
4. Amezrou R, RPS Verma, S Chao, RS Brueggeman, L Belqadi, M Arbaoui, S Rehman and S Gyawali 2018. Genome-wide association studies of net form of net blotch resistance at seedling and adult plant stages in spring barley collection. Molecular breeding, 38: 58. doi. org/10.1007/s11032-018-0813-2.

5. Andrew, C. 2008. The gladiator diet, how to eat, exercise, and die a violent death. Archaeology Magazine: 61(6), November/December 2008.

6. Behall, K.M., D.J. Scholfield and J. Hallfrisch. 2006. Barley -glucan reduces plasma glucose and insulin responses compared with resistant starch in men. Nutrition Research, 26: 644-650.

7. Bellucci, E, E. Bitocchi, D. Rau, L. Nanni, N. Ferradini, A. Giardini, M. Rodriguez, G. Attene and R. Papa. 2013. Population structure of barley landrace populations and gene flow with modern varieties. PLOS ONE 8: e83891

8. Berhanu B., A Fekadu and Berhane Lakew. 2005. Food barley in Ethiopia. pp 53-82, In: S. Grando and H. Gomez Macpherson (eds.). Food Barley: Importance, Use and Local Knowledge. Proceedings of the International Workshop on Food Barley Improvement, 14-17 January 2002, Hammamet, Tunisia. ICARDA, Aleppo, Syria.

9. Blake, T, V.C. Blake, J.G.P. Bowman and H. AbdelHaleem. 2010. Barley Feed Uses and Quality Improvement. Barley: Pp 522-531 In: Barley: Production, Improvement and Uses. Ed: S.E. Ullrich, Wiley-Blackwell, Iowa, USA.

10. Bockelman, H.E. and J. Valkoun. 2010. Barley germplasm conservation and resources. In: Barley: Production, Improvement, and Uses. S.E. Ullrich (ed). Wiley-Blackwell, Iowa, USA. Pp 144-159.

11. Bothmer, R von and N. Jacobsen. 1985. Origin, taxonomy, and related species. Pp.19-56 In: Barley, Ed: Rasmussen D.C. American Society of Agronomy Monograph No. 26.

12. Bothmer, R von, N. Jacobsen, C. Baden, R.B. Jørgensen and I. Linde-Laursen. 1995. An Ecogeographical Study of the Genus Hordeum, $2^{\text {nd }}$ edition. Systematic and Ecogeographical Studies on Crop Genepools, 7. IBPGR, Rome, Italy. 129 P.

13. Bothmer R. von, Sato K., Kamatsuda T., Yasuda S., Fischbeck G. 2003. The domestication of cultivated barley. In: Diversity in Barley (Hordeum vulgare). Eds. Von Bothmer R., van Hintum T., Knüpffer H., Sato K. Elsevier Press; Amsterdam, Netherlands. Pp 9-27. 
14. Braun, U., R.T.A. Cook, A.J. Inman and H.-D. Shin. 2002. The taxonomy of the powdery mildew fungi. In: The Powdery Mildews: A Comprehensive Treatise. R.R. Bélanger, W.R. Bushnell, A.J. Dik and T.L.W. Carver (eds.). American Phytopathological Society, St. Paul, MN, USA. Pp 13-55.

15. Brennan, C.S., L.J. Cleary. 2005. The potential use of cereal (1-3) (1-4)- $\beta$-D-glucans as functional food ingredients. Journal of Cereal Science, 42: 1-13.

16. Brockman, D.A., X. Chen X and D.D. Gallaher. 2013. Consumption of a high -glucan barley flour improves glucose control and fatty liver and increases muscle acylcarnitines in the Zucker diabetic fatty rat. European Journal of Clinical Nutrients, 52:1743-1753.

17. Brush, S.B. 1995. In situ conservation of landraces in centers of crop diversity. Crop Science, 35: 346-354.

18. Ceccarelli, S. and S. Grando. 1996. Drought as a challenge for the plant breeders. Plant Growth Regulation 20: 149-155.

19. Ceccarelli, S., S. Grando, F. Capettini and M. Baum. 2008. Barley Breeding for Sustainable Production. In: Breeding Major Food Staples. Ed: Kang, MS and Priyadarshan, PM. Blackwell Publishing, Iowa, USA. Pp 193-225.

20. Desta Beyene. 1987. Effects of liming and nitrogen and phosphorus fertilizers on grain yield of barley. Ethiopian Journal of Agricultural Science 9:1-13.

21. Dill-Macky, R., R.G. Rees and G.J. Platz. 1991. Inoculum pressure and the development of stem rust epidemics in barley. Australian Journal of Agricultural Research 42: 769-777.

22. El-Yousfi, Brahim and B. Ezzahiri. 2002. Net blotch in semi-arid regions of Morocco II - Yield and Yield-loss modeling. Field Crops Research 73, 81-93.

23. Endeshaw Bekele. 1983. A differential rate of regional distribution of barley flavonoid patterns in Ethiopia, and a view on the centre of origin of barley. Hereditas 98:269-280.

24. FAOSTAT. 2016. Food and Agriculture Organization of the United Nations Statistics Division portal. http:// faostat3.fao.org/ [accessed January 2017].

25. FAOSTAT. 2017. Food and Agriculture Organization of the United Nations Statistics Division portal. http:// faostat3.fao.org/ [accessed June 2018].

26. Fetch, T.G. and B.J. Steffenson. 1994. Identification of Cochliobolus sativus isolates expressing differential virulence on two - row barley genotypes from North Dakota. Canadian Journal of Plant Pathology, 16: 202-206.

27. Gamst, F.C. 1969. The Qemant: A pagan-Hebraic Peasantry of Ethiopia. Holt, Rinehart and Winston, New York, USA. P 111.

28. Grando, S., R. von Bothmer and S. Ceccarelli. 2001. Genetic diversity of barley: use of locally adapted germplasm to enhance yield and yield stability of barley in dry areas. Pp 351-372. In: Broadening the Genetic Base of Crop Production. H.D. Cooper, C. Spillane and T. Hodgink (eds). CABI, New York, USA/FAO, IPGRI, Rome, Italy.

29. Grando, S. and H. Gomez Macpherson. 2005. Food Barley: Importance, Uses and Local Knowledge. Proc. of the International Workshop on Food Barley Improvement, 14-17 January 2002, Hammamet, Tunisia. ICARDA, Aleppo, Syria.

30. Gyawali, S., M.L. Otte, S. Chao, J. Abderazzek, D.L. Jacob, R. Amezrou, and R.P.S. Verma. 2017. Genome wide association studies (GWAS) of element contents in grain with a special focus on zinc and iron in a world collection of barley (Hordeum vulgare L.). Journal of Cereal Sciences 77: 266-274.

31. Gyawali, S; Chao, S; Vaish, SS; Singh, SP; Rehman, S; Vishwakarma, SR; and Verma, RPS. 2018a. Genome wide association studies (GWAS) of spot blotch resistance at the seedling and the adult plant stages in a collection of spring barley. Molecular Breeding 38: 62 .

32. Gyawali, S. Reda, A. Verma, R.P.S. Brueggeman, R.S., Rehman, S. Loubna, B., Mustapha A., Tamang, P and Singh, M. 2018b. Seedling and adult stage resistance to spot form of net blotch (SFNB) in spring barley and stability of adult stage resistance to SFNB in Morocco. European Journal of Plant Pathology 1-13: 2018.

33. Hadjichristodoulou, A. 1995. Evaluation of barley landraces and selections from natural outcrosses of $H$. vulgare ssp. spontaneum with ssp. vulgare for breeding in semi-arid areas. Genetic Resources and Crop Evolution 42: 83-89.

34. Harder, D.E. and W.G. Legge. 2000. Effectiveness of different sources of stem rust resistance in barley. Crop Science 40: 826-833.

35. Joffe, A.Z. 1986. Fusarium Species: Their Biology and Toxicology.John Wiley \& Sons, New York, USA. P 588.

36. Keenan, J.M., M. Goulson, T. Shamliyan, N. Knutson, L. Kolberg and L. Curry. 2007. The effects of concentrated 
barley $\beta$-glucan on blood lipids and other CVD risk factors in a population of hypercholesterolemic men and women. British Journal of Nutrition 97:1162-1168.

37. Kilian, B., H. Ozkan, J. Kohl, A.V. Haseler, F. Barale, O. Deusch, A. Brandolini, C. Yucel, W. Martin and F. Salamini. 2006. Haplotype structure at seven barley genes: relevance to gene pool bottlenecks, phylogeny of ear type and site of barley domestication. Molecular Genetics and Genom 276: 230-241.

38. Hickey L.T., E.G. Silvia, A.P. Silvia, E.D. Juan, A.Z. Laura, A.F. Ryan, J.P. Greg, J.D. Franckowiak and M.J. Dieters. 2017. Speed breeding for multiple disease resistance in barley. Euphytica 213: 64 .

39. Li, J., T. Kaneko, L.Q. Qin, J. Wang and Y. Wang. 2003. Effects of barley intake on glucose tolerance, lipid metabolism, and bowel function in women. Nutrition 19: 926-929.

40. Lybbert, T. and D. Sumner. 2010. Agricultural Technologies for Climate Change Mitigation and Adaptation in Developing Countries: Policy Options for Innovation and Technology Diffusion, ICTSD-IPC Platform on Climate Change, Agriculture and Trade, Issue Brief No.6. International Centre for Trade and Sustainable Development, Geneva, Switzerland and International Food \& Agricultural Trade Policy Council, Washington DC, USA. P 28.

41. Marconi, E., M. Graziano and R. Cubadda. 2000. Composition and utilization of barley pearling byproducts for making functional pastas rich in dietary fibre and $\beta$-glucans. Cereal Chemistry 77:133-139.

42. Marshall, D. and R.L. Sutton. 1995. Epidemiology of stripe rust, virulence of Puccinia striiformis f. sp. hordei, and yield loss in barley. Plant Diseases 79: 732-737.

43. Martin M.; G Heidrun; H Axel.; B Sebastian; OT Sven et al 2017. Nature 544: 427-433.

44. Mathre, D.E. 1997. Compendium of Barley Diseases. American Phytopathological Society, St. Paul, MN, USA.

45. McGuire, S.J. 2008. Securing access to seed: Social relations and sorghum seed exchange in eastern Ethiopia. Human Ecology 36: 217-229.

46. McLean, M. S., Howlett, B.J., and Hollaway, G.J. 2009. Epidemiology and control of spot form of net blotch (Pyrenophora teres f. maculata) of barley: A Review. Crop Pasture Science 60: 303-315.

47. Miller, R.H. and Adugna Haile. 1988. Russian wheat aphid on barley in Ethiopia. Rachis 7: 51-52.
48. Molina-Cano, J.L. and J.,Conde. 1980. Hordeum spontaneum C. Koch emend Bacht. Collected in southern Morocco. Barley Genetics Newesletter 10: 44-47.

49. Molina-Cano, J.L., P. Fra-Mon, C. Aragoncillo and F. Garcia-Olmedo. 1987. Morocco as a possible domestication center for barley: Biochemical and agromorphological evidence. Theoritical and Appllied Genetics 73: 531-536.

50. Molina-Cano, J.L., M. Moralejo, E. Igatura and I. Romagosa. 1999. Further evidence supporting Moroco as a centre of origin of barley. Theoritical and Appllied Genetics 98: 913-918.

51. Molina-Cano J.L., Igartua E., Casas A., Moralejo M. 2002. New views on the origin of cultivated barley. In: Barley Science: Recent Advances from Molecular Biology to Agronomy of Yield and Quality. Edi: Slafer G. A., MolinaCano J. L., Savin R., Araus J. L., Romagosa I. The Haworth Press Inc., Binghamton, New York. Pp 15-29.

52. Molina-Cano, J.L., J.R. Russell and M.A. Moralejo. 2005. Chloroplast DNA microsatellite analysis supports a polyphyletic origin for barley. Theoritical and Appllied Genetics 110: 613-619.

53. Moralejo, M., I. Romagosa, G. Salcedo, R. SanchezMonge and J.L. Molina-Cano.1994. On the origin of Spanish two-rowed barleys. Theoritical and Appllied Genetics 87: 826-829.

54. Mulatu Bayeh and Grando Stefania (eds), 2011. Barley Research and development in Ethiopia. Proceedings of the 2nd National Barley Research and Development Review Workshop. 28-30 November 2006 at HARC, Holetta, Ethiopia. Pub: ICARDA, Aleppo, Syria. Pp xiv+391.

55. Nevo, E. 1992. Origin, Evolution, Population genetics and resources of wild barley, Hordeum spontaneum, in the fertile crescent. Pp 19-43 in: Barley: genetics, biochemistry, molecular biology and biotechnology. P.R. Shewry (ed). CAB International, Wallingford, UK.

56. Newman, C.W. and R.K. Newman 1992. Nutritional aspects of barley seed structure and composition. Pp 351-368 in: Barley: Genetics, biochemistry, molecular biology and biotechnology. P.R. Shewry (ed). C.A.B International, Wallingford, UK.

57. Newton, A.C., A.J. Flavell, T.S. George, P. Leat, B.J. Mullholland, L. Ramsay, C. Revoredo-Giha,J. Russel, B.J. Steffenson, J.S. Swanston, W.T.B. Thomas, R. Waugh, P.J. White, and I.J. Bingham.. 2011. Crops that feed the world. Barley: A resilient crop? Strengths and weaknesses in the context of food security. Food Security 3: 141-178. 
58. Orabi, J., J. Backers and A. Wolday. 2007. The Horn of Africa as a centre of barley diversification and a potential domestication site. Theoritical and Appllied Genetics 114: 1117-1127.

59. Pankin, A. and M von Korff 2017. Co-evolution of methods and thoughts in cereal domestication studies: a tale of barley (Hordeum vulgare). Current Opinion in Plant Biology 2017, 36:15-21.

60. Rao, H.S., O.P. Basha, N.K. Singh, K. Sato and H.S. Dhaliwal. 2007. Frequency distributions and composite interval mapping for QTL analysis in 'Steptoe'×'Morex' barley mapping population. Barley Genetics Newsletter 37: 5-20.

61. Salas, B., B.J. Steffenson, H.H. Casper, B. Tacke, L. Prom, T. Fetch and P.B. Schwarz. 1999. Fusarium species pathogenic to barley and their associated mycotoxins. Plant Disease 83: 667-674.

62. Schulze, E.D. 1988. Adaptation mechanisms of noncultivated arid-zone plants: useful lesson for agriculture? In: Drought research priorities for the dryland tropics. E.R. Bidinger and C. Johansen (eds). Patancheru, ICRISAT, India. Pp 159-177.

63. Shipton, W.A., W.J.R. Boyd, W.J.R. and S.M. Ali. 1974. Scald of barley. Review of Plant Pathology 53: 839-861.

64. Steffenson, B.J. 1992. Analysis of durable resistance to stem rust in barley. Euphytica 63:153-167.

65. Steffenson, B.J. 2003. Fusarium head blight of barley: impact, epidemics, management, and strategies for identifying and utilizing genetic resistance. Pp 241295 in Fusarium Head Blight of Wheat and Barley. K.J. Leonard and W.R. Bushnell (eds.). American Phytopathological Society, St. Paul, MN, USA.

66. Stroud, A. 1989. Weed Management in Ethiopia: an extension and training manual. FAO, Rome. $244 \mathrm{P}$.

67. Stubbs, R.W. 1985. Stripe Rust. Pp 61-101 in The Cereal Rusts: Diseases, Distribution, Epidemiology, and Control, Vol. 2. A.P. Roelfs and W.R. Bushnell (eds.). Academic Press, New York, USA.

68. Sullivan, P., E. Arendt and E. Gallagher. 2013. The increasing use of barley and barley by-products in the production of healthier baked goods. Trends in Food Science and Technology 29: 124-134.

69. T Jobie and T Gebremedhin. 2005. Delia steiniella Emden: newly recorded pest of wheat (Triticum aestivum) and its infestation level at Sinana, Ethiopia. Pest Management Journal of Ethiopia 9: 83-85.
70. Takele Negewo, Matias Mekuria \& Temam Hussien. 2006. Competition effects of major weed species at various densities on yield and yield components of barley (Hordeum vulgare L.). Pest Management Journal of Ethiopia 10: 53-59.

71. Tanksley, S.D. and S.R. McCouch. 1997. Seed banks and molecular maps: Unlocking genetic potential from the Wild. Science 277:1063-1066.

72. Taye Bekele. 2007. An overview of acid soils their management in ethiopia. In: proc. 3rd International Workshop on Water Management (Waterman) Project. Edi. Willibald Loiskandl, Universität für Bodenkultur Wien, Austria. September, 19-21, 2007. Haramaya, Ethiopia. P 27.

73. Tekauz, A. 1990. Characterisation and distribution of pathogenic variation in Pyrenophora teres $\mathrm{f}$. teres and Pyrenophora teres f. maculata from western Canada. Canadian Journal of Plant Pathology 12: 141-148.

74. Tester, M. and P. Langridge. 2010. Breeding technologies to increase crop production in a changing world. Science 327: 818-822.

75. Tinline, R.D. 1988. Cochliobolus sativus, a pathogen of wide host range. In: Advances in Plant Pathology: Genetics of Plant Pathogenic Fungi, Vol. 6. G.S. Sidhu (ed.). Academic Press, New York, USA. Pp 113-122.

76. Ullrich, S.E. 2010. Significance, Adaptation, Production, and Trade of Barley. In: Barley: Production, Improvement and Uses. S.E. Ullrich (ed). Wiley-Blackwell, Oxford. UK. Pp 3-13.

77. Van Ginkel, M. and F.C. Ogbonnaya. 2007. Novel genetic diversity from synthetic wheats in breeding cultivars for changing production conditions. Field Crops Research 104: 86-94.

78. Veteläinen, M. 1994. Exotic barley germplasm: variation and effects on agronomic traits in complex crosses. Euphytica 79:127-136.

79. Visioni A, S Gyawali, R Selvakumar, OP Gangwar, PS Shekhawat, SC Bhardwaj, AM Al-Abdallat, Z Kehel, and RPS Verma 2018. Genome wide association mapping of seedling and adult plant resistance to barley stripe rust (Puccinia striiformis f. sp. hordei). in India. Frontiers in Plant Science 9: 520

80. Wang, J., H. Raman, G. Zhang, N. Mendham and M. Zou. 2006. Aluminium tolerance in barley (Hordeum vulgaris L.): Physiological mechanisms, genetic and screening methods. Journal of Zhejiang University Science 7: 769-787. 
81. Wendy A. Harwood. 2012. Advances and remaining challenges in the transformation of barley and wheat. Journal of Experimental Botany 63 (5): 1791-1798.

82. Weerasena, J.S., B.J. Steffenson and A.B. Falk. 2004. Conversion of an amplified fragment length polymorphism marker into a co-dominant marker in the mapping of the Rph15 gene conferring resistance to barley leaf rust, Puccinia hordei Otth. Theoritical and Appllied Genetics 108: 712-719.

83. Wood. P.J. and M.U. Beer. 1998. Functional oat products. In: Functional foods-biochemical and processing aspects. G. Mazza (ed). Technomic Publishing Co., Inc. Lancaster, PA, USA. Pp 1-37.

84. Xiao, J., S. Grandillo, S.N. Ahn, S.R. McCouch, S.D. Tanksley, J. Li and L. Yuan. 1996. Genes from wild rice improve yield. Nature 384: 223-224.

85. Xu, X., Liu X, Ge S, Jensen JD, Hu F, Li X, Dong Y, Gutenkunst RN, Fang L, Huang L, Li J, He W, Zhang G, Zheng X, Zhang F, Li Y, Yu C, Kristiansen K, Zhang X, Wang J, Wright M, McCouch S, Nielsen R, WangJ, Wang W.2012. Resequencing 50 accessions of cultivated and wild rice yields markers for identifying agronomically important genes. Nature Biotechnology 30: 105-111.
86. Xu, Y.W. 1982. The origin and evolution of cultivated barley in China. Acta Genetica Sinica 9: 440-446.

87. Xue, A.G., H. Kehming, G. Butler, B.J. Vigier and C. Babcock. 2006. Pathogenicity of Fusarium species causing head blight in barley. Phytoprotection 87: 55-61.

88. Zemede Asfaw 1989. Relationships between spike morphology, hordeins and altitude within Ethiopian barley. Hereditas 110: 203-209.

89. Zemede Asfaw 1990. An ethnobotanical study of barley in the central highlands of Ethiopia. Biologisches Zentralblat 9:51-62.

90. Zemede Asfaw. 1996. Barley in Ethiopia: the link between botany and tradition. In: Barley research in Ethiopia: Past work and future prospects. G. Hailu and J.A.G. van Leur (eds). Proceedings of the First Barley Research Review workshop, 16-19 Oct. 1993. Addis Ababa, Ethiopia. Pp 182-192.

91. Zhan, J., B.D.L. Fitt, H.O. Pinnschmidt, S.J.P. Oxley and A.C. Newton. 2008. Resistance, epidemiology and sustainable management of Rhynchosporium secalis populations on barley. Plant Pathology 57:1-14 